\title{
The distribution of nutrients, dissolved oxygen and chlorophyll $a$ in the upper Gulf of Nicoya, Costa Rica, a tropical estuary
}

\author{
Jaime Palter ${ }^{1}$, Sandra León Coto $^{2} \&$ Daniel Ballestero ${ }^{3}$ \\ 1 Present address: Division of Earth and Ocean Science, Duke University, Durham, NC 27708 USA; jbp3@duke.edu \\ 2 Laboratorio de Química Marina, Universidad Nacional, Apdo. 86-3000, Heredia Costa Rica \\ 3 Laboratorio de Oceanografía, Universidad Nacional, Apdo. 86-3000, Heredia Costa Rica
}

Received 04-VII-2003. C Corrected 11-XII-2006. Accepted 18-XII-2006.

\begin{abstract}
In the Gulf of Nicoya on the Pacific Coast of Costa Rica, nutrient rich equatorial subsurface water (ESW) is upwelled in much of the lower gulf. These offshore waters are often regarded as the major source of nutrients to the gulf. However, for most of the year, the ESW has little influence on the nutrient content of the upper gulf, which has a distinct character from the lower gulf. The upper gulf, extending $40 \mathrm{~km}$ north of the restriction between Puntarenas Peninsula and San Lucas Island, is bordered primarily by mangrove swamps, is less than $20 \mathrm{~m}$ deep, and is less saline than the lower gulf. We surveyed the upper gulf for dissolved inorganic nitrogen, phosphate, silicate, dissolved oxygen, and chlorophyll in November 2000, January and July 2001. All nutrients are more concentrated in the upper gulf during the rainy and transitional seasons than the dry season, significantly so for phosphate and silicate. Throughout the year, nutrients tend to be much more concentrated in the less saline water of the upper gulf. This trend indicates that discharge from the Tempisque River predominantly controls spatial and temporal nutrient variability in the upper gulf. However, nutrient rich ESW, upwelled offshore and mixed to form a mid-temperature intermediate water, may enter the inner gulf to provide an important secondary source of nutrients during the dry season. Rev. Biol. Trop. 55 (2): 427-436. Epub 2007 June, 29.
\end{abstract}

Key words: tropical estuary, nutrients, dissolved oxygen, Costa Rica, Gulf of Nicoya.

Strong seasonality in precipitation dominates the climatic variability in the tropics. Thus, while day-length and temperature remain fairly constant, the land-sea flux of sediments, nutrients and organic matter to tropical estuaries can be highly seasonal and quite distinct from temperate estuaries (e.g. Nixon 1983, D'Avanzo et al. 1996). Furthermore, whereas temperate estuaries have been the subject of intense study, significantly fewer studies have been done on small and mid-size tropical estuaries in developing countries. Thus, the Gulf of Nicoya in Costa Rica, Central America is exceptional for a tropical estuary in that it has been the subject of over 100 studies, at least three of which focus on water column nutrient concentrations (Vargas 1995). Epifanio et al. (1983) conducted the first survey of water column nutrients and oxygen in the Gulf in 1979-1980, when the population of Costa Rica was roughly half of what it was at the time of this study. Valdés et al. (1987) next surveyed nutrients in the Gulf between May of 1980 and June of 1981. In 1995, inorganic nutrients in the water column of the Gulf were again thoroughly surveyed in the dry and rainy seasons (Kress et al. 2002). In this paper we present the results of a fourth study of the distribution of nitrate, nitrite, inorganic phosphate, silicate and dissolved oxygen in the Gulf of Nicoya in 2000-2001, in order to investigate the dominant sources of nutrients in the upper gulf and their impact on primary productivity and oxygen concentrations. This study is the first in Gulf 
of Nicoya to sample the upper gulf extensively in June, during the transition between the dry and rainy seasons in order to explore the full seasonality of the various nutrient fluxes to the estuary.

Study site: The Gulf of Nicoya is a tectonic estuary that extends approximately $80 \mathrm{~km}$ southward from the mouth of the Tempisque River to the Pacific Ocean. At the mouth of the Tempisque River, the gulf is less than $3 \mathrm{~km}$ wide and widens to approximately $50 \mathrm{~km}$ at its southernmost extension. The shape, bathymetry and hydrography of the gulf divide it into two distinct regions: the shallow upper gulf, north of the restriction between the Puntarenas Peninsula and San Lucas island, which is less than $20 \mathrm{~m}$ in depth and bordered primarily by mangrove swamps; and the lower Gulf, which deepens swiftly to $200 \mathrm{~m}$ at the mouth and is bordered by rocky cliffs (Voorhis et al. 1993). The subject of this study is the upper gulf.

Although the upper gulf represents only a small fraction of the total volume of the Gulf of Nicoya, it is an extremely important habitat and nursery ground for fish and shellfish. The upper gulf supports the largest populations of crabs, squid, and echinoderms (Maurer et al. 1984). The Atlantic blue crab, a support species for many important fisheries, lives predominantly in the upper gulf, only migrating further south to spawn (Dittel et al. 1985). By weight, more than half of all fish and nearly all of the shrimp and shellfish caught by artisanal fishermen are found in the upper gulf (INRECOSMAR 1998). In economic terms, artisanal fishermen are earning over 200 times as much in the upper gulf than in the lower gulf (INRECOSMAR 1998).

The upper Gulf of Nicoya receives unquantified amounts of anthropogenic discharge. It has experienced many of the consequences often associated with the anthropogenic nutrient enrichment of estuaries (NOAA 1997). In the rainy season the gulf can become stratified with bottom waters undersaturated in oxygen and high in salinity (Lizano 1998, Kress et al. 2002). There is a debate whether red tides, which have periodically plagued the gulf for at least 25 years and often prevent the sale of the gulf's shellfish, have become more frequent, longer-lasting and more toxic since the 1980's when there was not a single reported case of human illness from the ingestion of shellfish (Hargraves and Víquez 1981, Gocke et al. 1990). Hargraves and Víquez (1981) link the decay of the algae from these blooms to diminished dissolved oxygen concentrations in the bottom waters of the Gulf of Nicoya.

Most of the nitrogen in the lower gulf is entrained from offshore (Epifanio et al. 1983, Chaves and Birkicht 1996). Chaves and Birkicht (1996) concluded that the major source of nitrogen and phosphorus to the gulf is the Equatorial Subsurface Water (ESW), which is mixed throughout the water column by winds and turbulence and imported into the gulf by wind-driven advection. In their analysis, they observed no significant difference between the rainy and dry season concentrations, when averaged over the upper and lower gulf. The objective of this study was to understand the spatial and temporal variability of nutrient concentrations in the under-sampled upper gulf, in order to assess the dominant nutrient sources, their seasonal variability, and their impact on chlorophyll $a$ and dissolved oxygen concentrations.

\section{MATERIALS AND METHODS}

During three research cruises on the upper Gulf of Nicoya, samples were collected at ten stations at the surface, $5 \mathrm{~m}$ and either 10 $\mathrm{m}$ or $15 \mathrm{~m}$, depending on the total depth at each station (Fig. 1). The deepest sample was taken at $35 \mathrm{~m}$ at Station 1. The first cruise was conducted in the rainy season (November 30, 2000), the second in the dry season (January $30,2001)$ and the third in the transitional time between dry and rainy seasons (June 26, 2001). Each of the cruises was conducted between the hours of 1100-1800 local time, with the cruise track starting at Station 1 and progressing counterclockwise around the gulf, ending at Station 2 (Fig. 1). Each cruise was initiated during rising tide and completed at or just after 


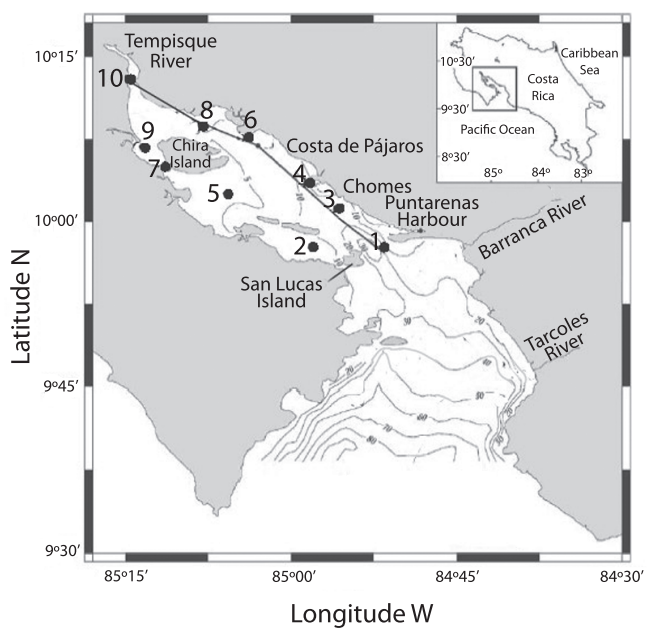

Fig. 1. Map of the sampling stations in the inner Gulf of Nicoya. The line marks the stations used to construct the vertical transects. Bathymetric contour interval is $10 \mathrm{~m}$.

the highest tide of the day. Approximate station locations were obtained using a map and landmarks with experienced navigators. Upon arrival at each station a reading for exact location was taken with a handheld Magellen GPS Field Pro V (accuracy $12 \mathrm{~m}$ ). On board, temperature and dissolved oxygen were measured using a YSI Model 58 dissolved oxygen meter. Secchi depth was measured using a standard 20 $\mathrm{cm}$ black and white Secchi disk.

With a 2-liter Niskin bottle, samples from each station were collected and placed in plastic $500 \mathrm{ml}$ bottles for the laboratory detection of $\mathrm{PO}_{4}, \mathrm{NO}_{3}, \mathrm{NO}_{2}, \mathrm{NH}_{4}, \mathrm{Si}(\mathrm{OH})_{4}$ and salinity with replicates at each depth. Due to analytical difficulty in developing a calibration curve for $\mathrm{NH}_{4}^{+}$, those analyses are not discussed below. All samples were immediately placed on ice and frozen upon arrival to the laboratory. The nutrient analyses were all carried out within two weeks using the colorimetric methods from Strickland and Parsons (1972), as briefly described here. The determination of nitrite was conducted by conversion to a colored azo dye. Nitrate was reduced to nitrite and then analyzed by the same method. Phosphate and silicate were both determined by the formation of a molybdenum compound and subsequent reduction to a blue dye. For the analysis of chlorophyll $500 \mathrm{ml}$ of water were filtered on board through GF/F filters, which were immediately placed in vials on ice in the dark. The chlorophyll was extracted with acetone the same night, agitated, and refrigerated for $12 \mathrm{hrs}$ in the dark. Within $24 \mathrm{hrs}$, the acetone extract was centrifuged, decanted and read with a spectrophotometer. The SCOR/UNESCO equations were applied to arrive at the concentration of chlorophyll in each sample (Strickland and Parsons 1972). Salinity was measured in the laboratory with a Hannah Instruments 9032 Microprocessor Bench Conductivity Meter. For all nutrient analyses from the second and third cruise, the absorbance of at least four standards and a blank were used in constructing a calibration curve. Seasonal variability in the gulf was considered using a Student's T-test, which compares variability between any two cruises to variability within a single cruise. The relationship between dissolved oxygen concentrations and chlorophyll concentrations were explored using a simple test for correlation.

\section{RESULTS}

The results of all analyses are summarized in Table 1. The upper Gulf's temperature was, on average, two degrees lower during the dry season cruise than both the rainy season and transitional cruises (for both T-tests comparing rainy season temperature observations to dry and transitional season, $\mathrm{T}>1.72$, d.f. $\geq 20$ and $\mathrm{p}<0.05)$. Silicate, phosphate, and nitrite average concentrations were all significantly lower in the dry season than the rainy and transitional (as above, $\mathrm{T}>1.72$, d.f. $\geq 20, \mathrm{p}<0.05$ ). Dry season concentrations of nitrate $(1.4 \mu \mathrm{M})$ were lower than rainy season concentrations (2.5 $\mu \mathrm{M})$, but not significantly so (T-test@1.2, d.f.= $21, \mathrm{p}=0.12$ ).

Regardless of season, surface dissolved oxygen concentrations tended to be near saturation throughout the upper Gulf, with lower concentrations in November and July at depths greater than $5 \mathrm{~m}$ (Table 1, Fig. 2). Chlorophyll 
TABLE 1

Averages, standard deviation (SD), maximum and minimum values of all variables for all depths and all stations, by season

November 30, 2000

(Rainy Season)
January 30, 2001

(Dry Season)
July 22, 2001

(Transitional)

\begin{tabular}{|c|c|c|c|c|c|c|c|c|c|c|c|c|}
\hline Temperature $\left({ }^{\circ} \mathrm{C}\right)$ & 28.6 & 0.9 & 29.9 & 26.9 & 26.5 & 1.1 & 28.4 & 24.9 & 28.9 & 1.2 & 30.6 & 27.3 \\
\hline Salinity (ppt) & 22.2 & 3.4 & 26.9 & 12.9 & 24 & 3.2 & 29.2 & 13.9 & 22.1 & 2.4 & 24.1 & 13.2 \\
\hline Nitrate $(\mu \mathrm{M})$ & 2.5 & 2.7 & 10.27 & $\begin{array}{c}\text { no } \\
\text { detect }\end{array}$ & 1.4 & 2.5 & 9.1 & $\begin{array}{c}\text { no } \\
\text { detect }\end{array}$ & 3.8 & 1.3 & 6.9 & 0.9 \\
\hline Nitrite $(\mu \mathrm{M})$ & 0.72 & 0.6 & 1.71 & 0.07 & 0.22 & 0.20 & 0.77 & 0.04 & 1.9 & 0.6 & 2.7 & 0.4 \\
\hline Phosphate $(\mu \mathrm{M})$ & 1.34 & 0.9 & 3.35 & 0.37 & 0.51 & 0.38 & 1.75 & 0.02 & 1.50 & 0.70 & 3.60 & 0.80 \\
\hline Silicate $(\mu \mathrm{M})$ & 64.8 & 49.3 & 165.3 & 10.2 & 17.4 & 25.7 & 127.7 & 2.4 & 39.9 & 27.4 & 115.4 & 8.1 \\
\hline $\begin{array}{l}\text { Dissolved Oxygen } \\
(\% \text { saturation) }\end{array}$ & 91.8 & 18.3 & 131.2 & 64.8 & 105.7 & 14 & 130.1 & 68.8 & 73.5 & 12.2 & 97.8 & 54.1 \\
\hline Chlorophyll a ( $\mu \mathrm{g} / \mathrm{l})$ & 7.0 & 3.4 & 12.63 & 1.29 & 7.7 & 2.5 & 15.6 & 3.3 & 8.7 & 3.8 & 19.7 & 4.2 \\
\hline Secchi depth (m) & & No d & lata & & 1.3 & 0.63 & 2.50 & 0.40 & 0.05 & 0.02 & 0.08 & 0.01 \\
\hline
\end{tabular}
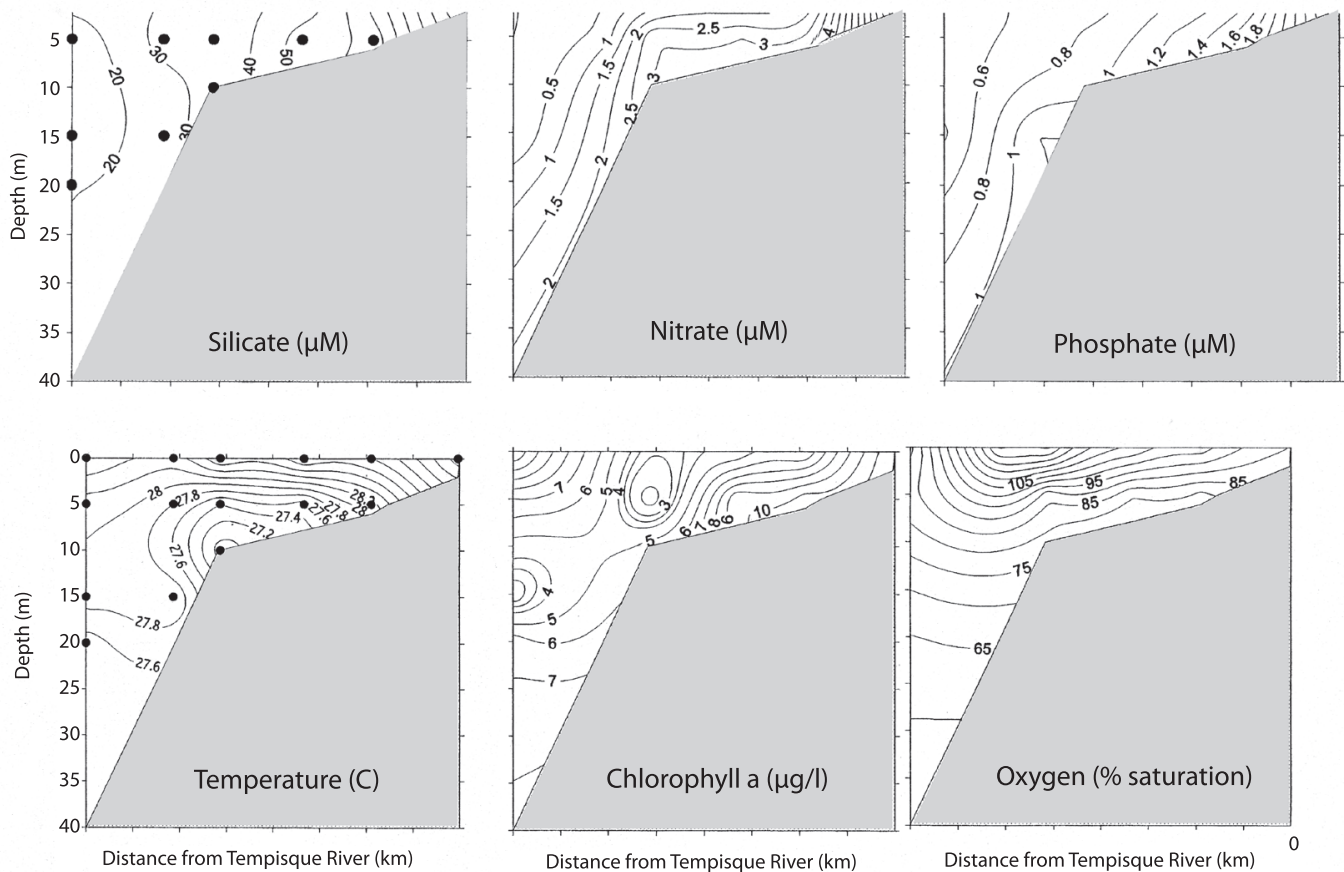

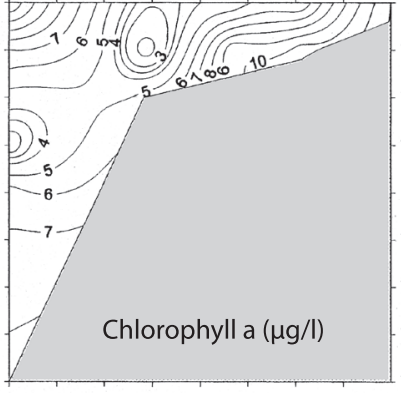

Distance from Tempisque River $(\mathrm{km})$

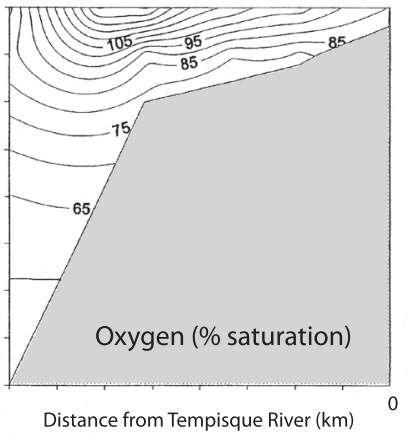

Fig. 2. Rainy season (November 30) distribution of silicate, nitrate, phosphate, temperature, chlorophyll $a$, and dissolved oxygen concentrations along an eastern transect of the Gulf of Nicoya (stations 1, 3, 4, 6, 8, 10, Figure 1). In transects with silicate concentrations and temperature, black points represent sampling locations. 
concentrations were spatially patchy, with a maximum in the mouth of the Tempisque River throughout the year, and a second peak near the Puntarenas Peninsula. Secchi depth reached a maximum of $2.5 \mathrm{~m}$ at Station 1 in January, and a minimum of $0.01 \mathrm{~m}$ at Station 10 in July (Fig. 1, Table 1).

Nitrate concentrations increased notably with proximity to the Tempisque River (Fig. 3). All surface nutrient distributions resemble that of nitrate, increasing steadily with proximity to the Tempisque River (data not shown). However, the spatial gradient in nitrate during the dry season cruise was distinct than for the other cruises. The nitrate is uniformly low $(<1$ $\mu \mathrm{M})$ over the entire upper gulf, from the north of Chira Island to the restriction between San Lucas and Puntarenas. However, an anomalous mid-gulf nitrate maximum of $2 \mu \mathrm{M}$ is observed at sampling stations 3 and 4 , on the eastern flank of the upper gulf, roughly $25 \mathrm{~km}$ from

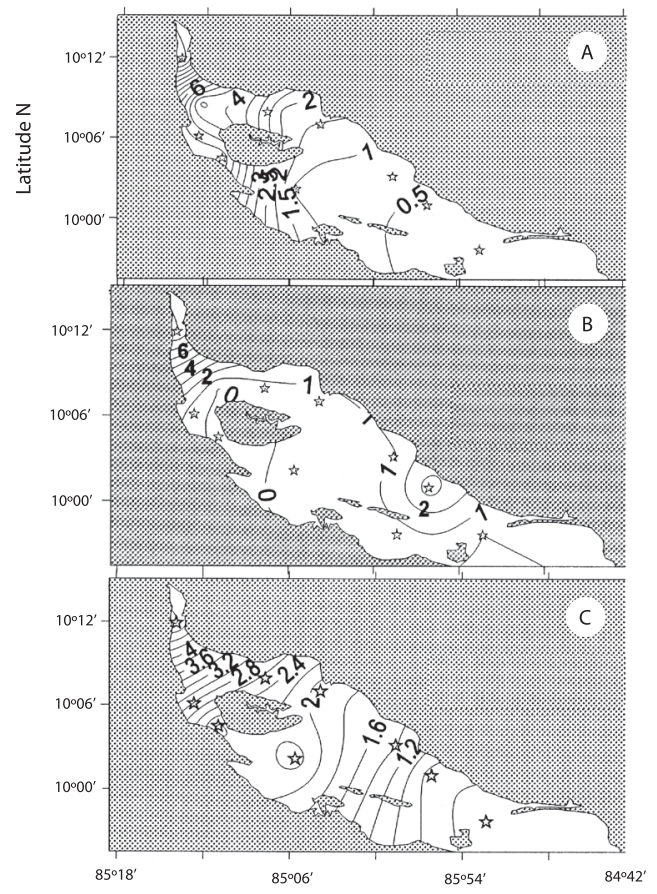

Fig. 3. Surface nitrate concentrations $(\mu \mathrm{M})$ in the upper Gulf of Nicoya during the (A) rainy season, 30 November 2000 (B) dry season, 30 January 2001 and (C) transitional season, 26 July 2001. Black points represent the sampling locations. comparable concentrations at the mouth of the Tempisque River (Fig. 2 and 4). The second nitrate peak was coincident with a local maximum in chlorophyll (Fig. 5) and a depression in sea surface temperatures on the day of the dry-season cruise of roughly $3^{\circ} \mathrm{C}$ (Fig. 6).

\section{DISCUSSION}

The turbidity and dissolved oxygen in the upper gulf appear to be strongly impacted by the magnitude of the freshwater and organic matter flux from the Tempisque River. During the June cruise, extremely turbid conditions were observed as a result of the first rains of the season fluxing large quantities of terrestrial sediment to the upper gulf. At this time a mean Secchi depth of only $0.05 \mathrm{~m}$ was observed (Table 1). This high turbidity coincides with a seasonal decline in dissolved oxygen (Fig. 2 ). This decline is likely caused by the oxidation of organic matter flushed into the system by the Tempisque River, whose discharge can elevate concentrations of suspended solids to $800 \mathrm{mg} / \mathrm{l}$ in the upper gulf during rainy season (Kress et al. 2002). Given the extreme turbidity of the water during the rainy season, it is

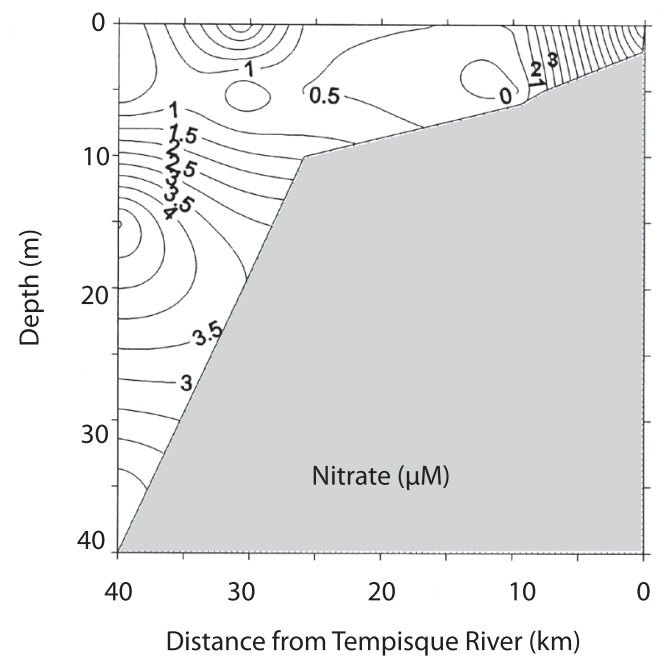

Fig. 4. January 30 nitrate concentrations $(\mu \mathrm{M})$ along an eastern transect of the Gulf of Nicoya (stations 1, 3, 4, 6, $8,10)$. 

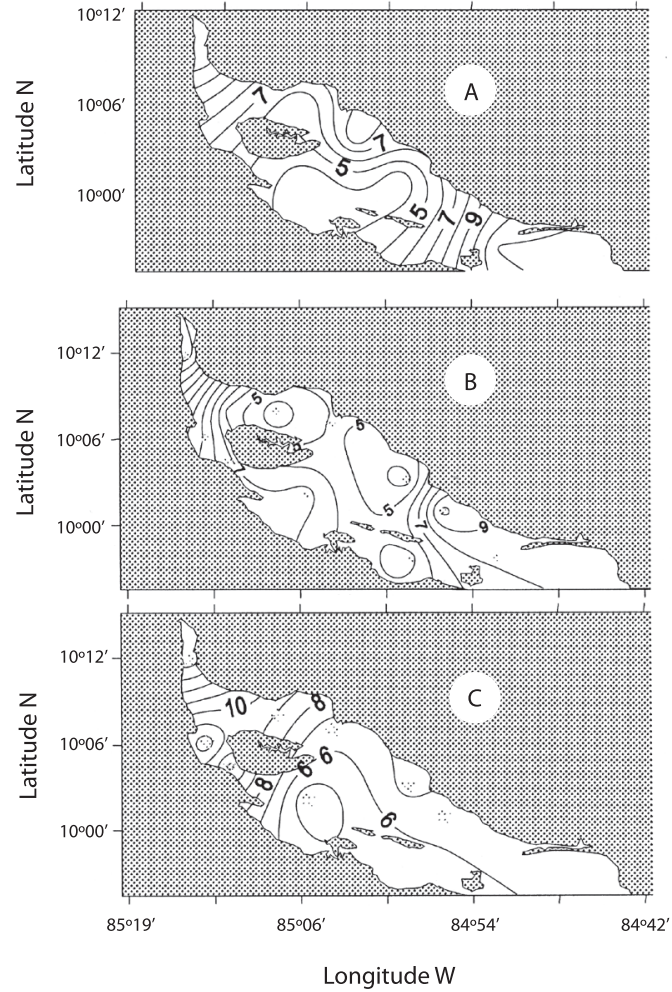

Fig. 5. Contours of surface chlorophyll a concentrations $(\mu \mathrm{g} / \mathrm{L})$ in the upper Gulf of Nicoya during $(\mathrm{A})$ rainy season, 30 November 2000, (B) dry season, 30 January 2001 and (C) transitional season, 26 July 2001. Black points represent sampling stations. expected that primary productivity in the gulf is light limited, and, therefore, the pool of autochthonous organic material is likely far smaller than that supplied by advective fluxes from the Tempisque River (Gocke et al. 2001). In the tropics during times of high river discharge, the oxidation of fine organic material in an estuary's floodwaters commonly leads to oxygen undersaturation (Eyre and Balls 1999). Vertical salinity stratification may also play a role in lowering the gulf's oxygen concentration, as freshwater input may reduce air-sea gas exchange with the bottom waters of the gulf (Fig. 2).

In addition to organic material and sediment, inorganic nutrients appear to be supplied primarily by the Tempisque River, throughout the year. Concentrations of all nutrients are highest in the mouth of the Tempisque River and decrease rapidly with distance from the river. Likewise, chlorophyll concentration, a proxy for phytoplankton biomass, is maximum at the mouth of the Tempisque River. However, nitrate and chlorophyll concentration are otherwise uncoupled, as there is considerable spatial patchiness in surface chlorophyll concentration throughout the upper gulf while nitrate increases continuously towards the river (Fig. 5). In patches where nitrate reaches non-detectable

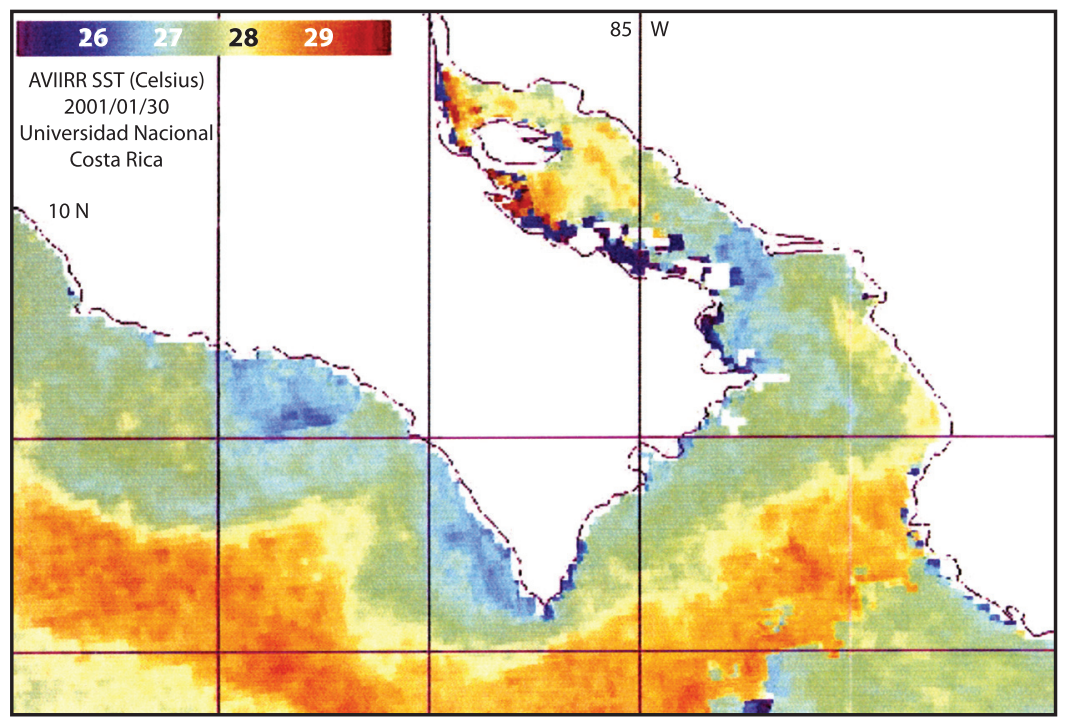

Fig. 6. Daily composite AVHRR sea surface temperature, Gulf of Nicoya, January 30, 2001. 
levels, chlorophyll concentrations can be as high as $9 \mu \mathrm{g} / \mathrm{l}$, which suggests that the nitrate may be entirely consumed by phytoplankton in these regions (Fig. 3 and 5). Dissolved oxygen concentrations for all seasons tend to be weakly anticorrelated with chlorophyll concentrations, a trend also observed by Kress et al. (2002) in 1995-1996. Such anticorrelation may suggest that the consumption of oxygen during subsurface decay of organic matter exceeds the oxygen produced by photosynthesis and delivered by mixing with the atmosphere.

In addition to the Tempisque's strong impact on spatial variability of nutrients in the upper Gulf, it also exerts the dominant control on the temporal nutrient variability. In a 12-year time series of discharge rates from a gauge in the upper Tempisque River made available for this study by the Instituto Costarricense de Electricidad, high seasonal variation in Tempisque River flow rate is evident (data not shown). Discharge is lowest in March and April, begins rising in response to increased rainfall in May, and peaks from September to November. By the date of the transitional season cruise in June, rain had been falling continuously over the Tempisque River watershed for nearly a month. As in November, a plume of sediment-laden water flowed from the river into the gulf. Thus, the averages of phosphate and silicate concentrations are indistinguishable in November and June, but significantly lower in January when the discharge rate from the Tempisque River is, on average, half of its rainy season values. If the major source of nutrients in the upper gulf were offshore water delivered by wind-induced mixing, one would instead expect to see higher nutrient concentrations during the dry season cruise, as large wind events were observed in January 2001 (Enrique Coen, unpublished data). However, the fact that there is no significant seasonal difference for upper gulf average nitrate concentrations, may suggest that there is a secondary source of nutrients that is not affected by seasonal changes in river discharge. Indeed, a small secondary peak of nitrate north of Puntarenas observed during the
January cruise supports this hypothesis (Fig. 2 and 4). The two most probable secondary sources of nitrate at this location are discharges from Estero Puntarenas and the entrainment of offshore waters. Given that nitrate levels were elevated at this location only during the dry season suggests that the source is not likely the Estero Puntarenas, whose discharge, and thus nutrient input, would be greater in the rainy season. Additionally, when viewed in transect, the high-nitrate water appears to be entering the upper gulf from offshore, at a depth of roughly $20 \mathrm{~m}$ (Fig. 4).

A satellite image of the Gulf from the day of the dry season cruise further suggests that offshore water is the source of the spatially anomalous nitrate (Fig. 6). The image shows temperatures of less than $26^{\circ} \mathrm{C}$ in the region of the nitrate peak, indicative of the entrainment and upwelling of offshore thermocline water. A possible explanation for such upwelling involves synoptic wind events that occasionally breach the mountains of the Cordillera Central through discontinuities in elevation of only $500-1000 \mathrm{~m}$ (Brenes et al. 2003). Such wind events have been linked to upwelling in the Gulf of Nicoya and a lowering of the surface temperature by as much as $3.5^{\circ} \mathrm{C}$ (Brenes et al. 2003). In January 2001, in the week leading up to our cruise, vigorous wind-induced mixing observed along the Pacific coast of Costa Rica and Nicaragua, caused the shoaling of the thermocline to between $10-25 \mathrm{~m}$ in the surface offshore waters (Enrique Coen, unpublished data). This cold offshore water likely entered the lower gulf along the bottom and was mixed by wind and tides with less saline water from the upper gulf to form an intermediate water mass, as has been observed in a previous study by Voorhis et al. (1983). The depressed temperatures observed in the upper gulf (Fig. 6) are consistent with enhanced mixing with this cold intermediate water, the probable source for the second nitrate peak. This observation is in agreement with the high nutrient concentrations calculated for intermediate water in the dry season in 1995-1996 (Kress et al. 2002). It also supports Chaves and Birkicht's (1996) 
theory that Equatorial Subsurface Water (ESW) introduces nutrients into the gulf.

However, even in the dry season, the nutrient concentrations at the mouth of the Tempisque are more than double the concentrations at the southern end of the upper gulf, suggesting that nutrient fluxes to the upper gulf are likely dominated by landside sources throughout the year. More data are needed on the volume and nutrient concentrations of the Tempisque River discharge and the ESW to accurately quantify their relative nutrient fluxes to the upper gulf. It is interesting to note that the offshore nutrient flux occurs at the time of year and in the region of the upper gulf where turbidity is lowest. At this time and location, primary productivity is more likely to be nutrient limited than light limited. In contrast, in the near-shore regions, during the rainy season, primary productivity is likely light-limited as Secchi depth is on the order of 0.1 m (Córdoba-Muñoz 1993, Gocke et al. 2001). Thus, the impact of offshore water on primary productivity could be disproportionate to its volume. In addition, the offshore source may deliver distinct nutrient ratios from the terrestrial sources, thereby permitting unique phytoplankton assemblages. Thus, the biological impact of an offshore nutrient source remains an open question.

In summary, the upper Gulf of Nicoya has lower concentrations of nitrate and nitrite than many North American estuaries with more densely settled urban watersheds (Table 1, Nixon 1983, EPA 1999), but it is enriched in phosphate when compared to many of the same systems. On average, the nutrient concentrations observed in this study are not discernibly different from the averages obtained by Kress et al. (2002) or similar studies in 1979-1980, 1981-1982 (Epifanio et al. 1983, Valdés et al. 1987). However, the rainy season maxima for nitrate, nitrite, and phosphate, which are always found in the mouth of the Tempisque, are higher in the current study than each of the previous ones (Epifanio et al. 1983, Valdes et al. 1987, Kress et al., 2002). Kress et al. (2002) use mixing diagrams to estimate nutrient concentrations in the freshwater of the Tempisque River. Their estimates place it among the most nutrient-enriched rivers of the world, with anthropogenic nutrient sources potentially increasing. To our knowledge, no data are available to accurately quantify the use of fertilizers and other sources of nutrients in the Tempisque watershed. The data available at this time are not sufficient to capture any long-term trend in nutrient contamination in the Gulf of Nicoya, as the seasonal and interannual variability swamp any potential long-term trend. Continued seasonal sampling is necessary to quantify the relative contributions of offshore and terrestrial sources of nutrients and their impact on the estuarine ecosystem within the Gulf, and to capture any long-term trends during this critical period of Costa Rica's development.

With the data from this study it is clear that the offshore nutrient input to the upper Gulf of Nicoya is not the dominant control on the spatial and temporal distribution of nutrients. Here we show that freshwater flux from the Tempisque River is likely the largest source of nutrients to the upper Gulf of Nicoya throughout the year. Although the importance of ESW in the lower gulf should not be underestimated, our observations suggest that nutrients in the upper gulf are supplied primarily from terrestrial and not oceanic sources.

\section{ACKNOWLEDGMENTS}

We are grateful to Universidad Nacional's Laboratorio de Química Marina and Tatiana Coto Quintana for performing the analysis of the samples, Milton and Diana Lieberman for coordinating this collaboration and offering guidance at various stages of the project, INCOPESCA and Berní Marin for providing a boat and captain for each sampling mission, and the Fulbright Foundation for funding the opportunity for this international research. 


\section{RESUMEN}

Las aguas subsuperficiales ecuatoriales (ESW) que entran por la parte externa del Golfo de Nicoya de Costa Rica, se consideran una fuente importante de nutrientes para el estuario. Sin embargo, durante la mayoría del año las ESW tiene una influencia pequeña en la parte interna del golfo, que es oceanográfica y biológicamente diferente de la parte externa. La parte interna está ubicada desde la península de Puntarenas hasta la boca del Río Tempisque, $40 \mathrm{~km}$ al norte; es un área que se caracteriza por un importante aporte de agua dulce, está rodeada de manglares y tiene menos de $20 \mathrm{~m}$ de profundidad. En este estudio se midieron concentraciones de nitrato, nitrito, fosfato, silicato, oxígeno disuelto y clorofila $a$ en la parte interna del golfo en noviembre 2000 , enero y julio 2001 . Todos los nutrientes están concentrados en la parte interna del golfo durante la época lluviosa y de transición, y las concentraciones de fosfatos y silicatos son significantivamente diferentes respecto a las concentraciones en época seca. Durante todo el año los nutrientes muestran concentraciones mayores en las aguas más dulces cerca el Río Tempisque. Esto indica que las descargas del Río Tempisque dominan la variabilidad espacial y temporal en la parte interna. Además, los vientos alisios inducen la surgencia de ESW durante la estación seca, constituyendo una posible fuente secundaria de nutrientes durante esta época.

Key words: estuario tropical, nutrientes, oxígeno disuelto, Costa Rica, Golfo de Nicoya.

\section{REFERENCES}

Chaves, J. \& M. Birkicht. 1996. Equatorial subsurface water and the nutrient seasonality of the Gulf of Nicoya, Costa Rica. Rev. Biol. Trop. 44 (Suppl.3): 41-47.

Córdoba-Muñoz, R. 1993. Productividad primaria en la columna de agua, Golfo de Nicoya, Costa Rica. Tesis de Maestría, Universidad de Costa Rica, San José, Costa Rica.

D’Avanzo, C. \& J. Kremer. 1996. Ecosystem production and respiration in response to eutrophication in shallow temperate estuaries. Mar. Ecol. Prog. Ser. 141: 263-274.

Dittel, A.I., C.E. Epifanio \& J.B. Chavarria. 1985. Population biology of the Portunid Crab Callinectes arcuatus Ordway in the Gulf of Nicoya, Costa Rica, Central America. Estuar. Coast. Shelf Sci. 20: 593602.
EPA. 1999. Condition of the mid-Atlantic estuaries. Document 600-R-98-147. Environmental Protection Agency, Washington, DC.

Epifanio, C.E., D. Maurer \& A.I. Dittel. 1983. Seasonal changes in nutrients and dissolved oxygen in the Gulf of Nicoya, A tropical estuary. Hydrobiologia 101: 231-238.

Eyre, B. \& P. Balls. 1999. A comparative study of nutrient behavior along the salinity gradient of tropical and temperate estuaries. Estuaries 22: 313-326.

Fielder, P.C. 2002. The annual cycle and biological effects of the Costa Rica Dome. Deep-Sea Res. I. 49: 321338 .

Gocke, K., J. Cortes \& M.M. Murillo. 2001. The annual cycle of primary productivity in a tropical estuary: The inner regions of the Golfo de Nicoya, Costa Rica. Rev. Biol. Trop. 49 (Suppl. 2): 289-306.

Gocke, K., J. Cortés \& Inicial?Villalobos. 1990. Effects of red tides on oxygen concentration and distribution in the Golfo de Nicoya, Costa Rica. Rev. Biol. Trop. 38 (2B): 401-407.

Hargraves, P.E. \& R. Víquez. 1981. The dinoflagellate red tide in Costa Rica. Rev. Biol Trop. 29: 31-38.

INRECOSMAR. 1998. Documento 5: Estado del Conocimiento en el AMUN Golfo de Nicoya. Instituto de Recursos Marinos, San José, Costa Rica.

Kress, N., S. Brenner, S. Leon Coto, C.L. Brenes \& C. Arroyo. 2002. Horizontal transport and seasonal distribution of nutrients, dissolved oxygen and chlorophyll- $a$ in the Gulf of Nicoya, Costa Rica: a tropical estuary. Cont. Shelf Res. 22: 51-66.

Lizano, O.G. 1998. Dinámica de las aguas en la parte interna del Golfo de Nicoya ante altas descargas del Río Tempisque. Rev. Biol. Trop. 46 (Supl. 6): 11-20.

Maurer, D., C.E. Epifanio, H. Dean, S. Howe, J.A. Vargas, A.I. Dittel \& M. Murillo. 1984. Benthic Invertebrates of a tropical estuary: Gulf of Nicoya, Costa Rica. J. Nat. Hist. 18: 47-67.

Nixon, S.W. 1983. Estuarine Ecology: A comparitive and experimental analysis using 14 estuaries and the MERL microcosms. EPA, Kingston, Rhode Island.

NOAA. 1997. NOAA's estuarine eutrophication survey. Office of Ocean Resources Conservation and Assessment. Silver Spring, Maryland, USA 
Strickland, J.D.H. \& T.R. Parsons. 1972. A pratical handbook of seawater analysis. Bull. Fish. Res. Board of Canada, Ottawa, Canada. 310 p.

Valdés, J., C.L. Brenes, E. Solís \& M. Mendelewicz. 1987. Propiedades físico químicas de las aguas del Golfo de Nicoya, Costa Rica. Ingeniería Ciencia Química. 11: $21-25$.
Vargas JA. 1995. The Gulf of Nicoya estuary, Costa Rica: Past, present, and future cooperative research. Helgol. Meer. 49: 821-828.

Voorhis, A.D., C.E. Epifanio, D. Maurer, A.I. Dittel \& J.A. Vargas. 1983. The estuarine character of the Gulf of Nicoya, an embayment on the Pacific coast of Central America. Hydrobiologia 99: 225-237. 